\title{
"Push" and "Pull" Moves in Hispanic and Swedish Negotiation Talk
}

\begin{abstract}
In negotiations recorded on video-tape under near-identical conditions in Mexico, Spain and Sweden, two types of action were studied, defined as (1) affirming one's own party's position or image ("push"), and (2) attracting the other party by means of strengthening that party's position and image, or by underscoring the bonds between each parties ("pull"). A tentative typology of "push" vs. "pull" moves is proposed, including three mixed types, which are named "disguised", "linked" and "ambiguous" push/pull moves. The three nationality groups are compared in terms of the suggested typology, and analogous features are found between conversational analysis data and sociological/anthropological reports on Scandinavian, Spanish and Mexican culture.
\end{abstract}

\section{Introduction}

The purpose of the present paper is to give a preliminary account of culturally determined differences in the discourse and interaction of Hispanic and Scandinavian trained negotiators. The perspective underlying the description of the negotiators' behaviour involves a rather traditional classification in terms of "pull" and "push" styles (e.g. Karrass 1974 or Nierenberg 1973). A fundamental assumption, which depends largely on activity theory (cf. e.g. Allwood 1980 or Duranti 1990), may be spelled out as follows: the core component of the activity complex labeled "negotiating" - the component which is the object of the various attempts made in order to define what a negotiation is - can be meaningfully described in terms of three different types of interactive strategies: pull, push and avoidance strategies. Since the avoidance type strategy has proven to be fairly scarce in our data (see the following section), we have concentrated our efforts on studying the other two main types of negotiating behaviour.

Although the labels "push" and "pull" at a superficial glance may seem self-explanatory, some effort should be made to give them a more clear-cut and-if possible-a more operational definition. In studies dealing with negotiations and negotiation interaction, the opposition pair "competitive/co-operative", also referred to as "distributive/integrative", 
has frequently been used in describing negotiators' style or overall behaviour, as well as the atmosphere that characterizes a negotiation (cf. Donohue 1981). The pull/push contrast bears resemblance to this opposition, but will be attributed exclusively to smaller units of communicative behaviour, viz. what is generally referred to in studies of discourse analysis and other branches of pragmatics as "speech acts" (Searle 1979 and innumerable followers) or "communicative acts" (Allwood 1976). Here, we prefer to call these units "moves" (see section 2). A "push" move, then, will be understood as a discourse unit that implies some act of self(or own-party-)assertiveness related to a topic of the negotiation, whereas a "pull" move will be understood as a discourse unit that constitutes an act of attracting the other party by means of strengthening that party's image, position or bond with the own party, in connection with some topic of the negotiation.

At this point, it becomes obvious that the pull/push opposition is related to the Goffmanian concept of face (Goffman 1972), further developed by Brown and Levinson (1986). A push move, from the perspective of face theory, may be described as an act, which aims to strengthen Self's (i.e. one's own, or the home party's) face (i.e. shared image of behaving in a socially desirable manner), whereby Other's (i.e. the opposite party's) face may turn out to be threatened or diminished to a greater or lesser extent. A pull move, on the other hand, will be understood to carry the effect of strengthening Other's face-possibly, at times, at the cost of Self's face. In our study, it should be pointed out, face theory will not be subject to any more thoroughgoing treatment than this very remark. In particular, the Brown/Levinson distinction between "positive" and "negative" face will not be taken into account, since its relevance to the present study is by no means obvious.

\section{The data}

The present study is based on the analysis of transcripts from videorecorded negotiation activities (cf. Fant 1989, 1992a, 1992b; Grindsted 1990). These were not authentic negotiations, but simulations carried out by teams of trained negotiators, within the framework of advanced negotiation training seminars. Both the video-recording of the simulations and the simulations themselves were natural components of the seminars; their aim was to make the participants aware of their behaviour in order for them to learn ways to improve their technique. 
Data for this study has been obtained from Mexico, Spain and Sweden. Luckily, the training seminars in which the recordings were made, had nearly identical set-ups in each of the three countries. This is due to the fact that the same seminar design, originally developed in the U.S., was translated into the respective languages, and has been regularly put into practice in all three countries. In addition, the three simulation cases that were performed in these four-day long seminars, were practically identical; therefore, the task to be carried out by Mexican, Spanish and Swedish negotiators was almost the same. These circumstances, of course, have the advantage of creating a particularly high degree of comparability among the three sets of data.

Our observations were made solely on the basis of one simulation case, here named the CATALYST case. In this negotiation, the two parties are not completely equal in power. The development department of the big multinational company has the power to decide whether the products invented by the research laboratory will be launched or not. Moreover, both parties are strongly dependent upon each other for survival, and at the same time, some of the issues on the agenda are volatile and constitute a considerable challenge to the unity and co-operative spirit of the parties. Thus, there are strong forces which favour both pull and push action.

Although it is true that the simulations were carried out under circumstances which clearly favoured natural behaviour (cf. Fant 1992a), and that independent observers have hardly been able to detect any unnatural elements in the negotiations (Fant et al., forthcoming), some features should be indicated that constitute important differences between these negotiations and one hundred percent authentic ones. One such feature is the time limit stipulated in the instructions to the participants who were told to be finished in 30 minutes' time, or else they would be interrupted. This stress factor is probably responsible for another feature which may seem artificial, viz. the low proportion of avoidance moves, a class of behaviour which is reported to occupy a considerable amount of time in natural negotiations (Lampi 1990). This is the main reason why avoidance moves have been excluded from this study, which solely deals with clear-cut pull and push moves.

For the present purposes, we have studied three different actualizations of the CATALYST case from each country, whichs means a corpus of nine recordings altogether, approximately $41 / 2$ hours long total, with roughly 11/2 hours each of Mexican, Spanish and Swedish data. 


\section{Method}

The transcripts from the nine video-recorded negotiations were analyzed in several steps. In a first reading, sequences addressed to topics that did not belong to the agenda, and that could not be unequivocally labeled as belonging to the core activity of negotiating, were excluded. Thereupon, relevant units were tentatively identified and described in terms of labels traditionally used for describing "speech acts".

From a theoretical point of view, such a procedure is by no means non-problematic. Both speech act typologization and the way in which acts in discourse may be isolated and identified are unsettled issues, and scientific consensus is far from being attained in this area. The very concept of "speech act" may even be questioned. Investigations made in recent years have shown, among other things, that speech acts can be described as complex structures, in terms of "head acts" and "supportive moves" (Blum-Kulka et al. 1989), and that a "supportive move" under certain circumstances may appear alone without a "head act" appearing on the surface. In this study, we have chosen to use only one label, namely "move", to refer to the units considered relevant. This term will betentatively-defined as a configuration of utterances which appear in emergent, interactive discourse, and which may be interpreted as a unit precisely because it is governed by one main illocutionary force.

One additional criterion should be added: for a move to be recognized as such by an audience, we believe it is necessary that it be followed by some sort of response in the addressee (cf. Firth 1990:13 or Bilmes 1986:133). This criterion, as applied to the present study, has led to the effect that moves, which from the perspective of communicative intentions could qualify as instances of pull or push, have not been registered as such in case they turn out to have been misunderstood-or simply overlooked - by the other party.

On the basis of the earlier mentioned preliminary labeling procedure, the categories found were listed, and to the extent that this was considered feasible, were interpreted in terms of pull and push action (section 3). Afterwards, a new systematic reading was carried out in order to check for consistency.

This coding of negotiation moves in the Mexican, Spanish and Swedish negotiators' verbal interaction has provided the basis for a tentative contrastive description of their styles of negotiating (section 4). Finally, our observations will be seen in relation to different reports on the respective national patterns of behaviour (section 5). 


\section{Classification of moves}

Most of the variety of moves that we have been able to identify can actually be classified without any greater difficulty in terms of push vs. pull action. There remain, however, a few more complex cases, the complexity of which seems to be related to the fact that one type of move may function as a vehicle for another, superordinate goal (cf. Allwood 1976). We will refer to these as cases of either disguised or linked moves. Furthermore, one should be aware of the fact that although the categories pull and push are understood as opposing one another, they are by no means to be thought of as mutually exclusive. It is not surprising, then, that some moves may be characterized simply as ambiguous or twovalued.

One extremely important issue that was raised in connection with the listing of moves is to what extent a specific type of move will be understood as an instance of pull or push independently of culture, or even if the same set of labels could be used for different cultures (Wierzbicka 1992). Some aspects of this issue will be addressed later on (section 4). But before that, the categories singled out will be discussed in more general terms.

\subsection{Push moves}

The moves that were labeled as push activities in our data were further sub-categorized into three groups: basic initiatives, argumentative moves and assertive moves.

Basic initiatives are acts that are seen as essential to the activity of negotiating, even though they are fairly infrequent with regard to other more peripheral moves. The most "central" move that belongs to this type is making a bid, that is, coming up with a proposal for the solution of the main, or one of the main issues of the negotiation (e.g. telling a price). At times, the act of making a bid will refer only to one's own party's interests, and could then be labeled making a claim. ("We want you to do this before next week"). Another type of basic initiatives are proposals that do not precisely address the main issue, but rather the agenda or the way in which things should be treated ("Let's talk about this first").

Argumentative moves are defined as moves that serve the purpose of supporting a claim, opinion or proposal, or of supporting another argument that supports the claim made in the first place (and so forth), in 
which case we speak of argumentative chains. An argumentative move may also serve the purpose of weakening or invalidating the other party's argument, and also one's own "counter-argumentation" (van Eemeren et al. 1983), i. e. apparent concessions made to the opposite opinion. Furthermore, certain moves contain arguments that are new, whereas other moves just repeat earlier given arguments (Andersen 1990). The moves classified as argumentative were thus subcategorized according to the following properties:

- argument directly vs. indirectly supporting a claim

- argument for vs. argument against a claim

- new vs. iterated argument

For a push move to qualify as argumentative in our listing, it is required that the putative argument be presented so as to show logical connection with what it is supposed to support, and that it should not solely consist in a statement of the speaker's liking/disliking or approval/disapproval. However, there are borderline cases (such as: "Don't do this.Why?-Because it would seriously affect our good relationship"), in which it seems justified to classify the move as "argumentative" and "assertive" at the same time.

A third class of push moves, which we have labeled assertive moves, should in fact be understood as "non-argumentative although clearly selfaffirmative behaviour". The category of "basic initiatives", such as making bids, claims and proposals, was not included, however, in this class. It goes without saying that this category is a rather complex one. According to our typology, it includes the following sub-classes:

(1) Making valuating statements. These may be negative or positive: making a valuation always implies the affirmation of one's right and power to make it. In the case of positive valuation, however, there may be an overlap with the pull move giving appraisal.

(2) Rejecting the other party's claim, bid or opinion. Acts of this kind may, of course, be followed up by arguments and argumentative chains.

(3) Setting conditions for the other party in view of possible rewards or punishments. Here, acts of threatening and warning are included (the conditional aspects being explicitly or implicitly stated)

(4) Admonishing or advising the other party.

(5) Reprehending the other party, including holding the other party responsible for negative action and negative consequences. This type and 
the two previous ones are built upon an overt or covert act of valuation, although they possess additional features.

(6) Requiring justifications from the other party. This type should be kept separate from the following, "weaker" act of assertiveness:

(7) Requesting information from the other party. Here, again, there is a possibility of overlap with a pull move, namely yielding the initiative to the other party.

(8) Giving such information that explicitly or implicitly affirms one's own party's authority or power. This type presents another case of possible overlap with argumentation, since this kind of move may well occur in support of a claim, opinion, proposal, or be addressed to another argument.

It should be kept in mind that there are other types of assertive moves, which are not directly addressed to any topic of the negotiation itself, but may, for instance, be connected with the regulation of interaction in general. One such type, with regard to which there is considerable divergency among the three nationalities in our data, is "claiming attention for oneself". These types will not, however, be taken into account here.

One dimension that has not been considered so far, is the degree to which push moves, in particular the assertive sub-type, are produced in an attenuated, "hedged" fashion. Considerable differences between the three nationality groups have been found in this respect, and some of these aspects will be subject to comment in section 4 .

\subsection{Pull moves}

Three main types of pull behaviour were distinguished: yielding, acknowledging and "we-strengthening".

Yielding moves are moves which, in essence, aim at strengthening the other party's position by weakening one's own. The following sub-types have been identified:

(1) Accepting explicitly the other party's claim, proposal or opinion.

(2) Providing information asked for.

These two categories imply, in one way or another, "giving in" to the other party. The former type of move does not normally occur in an isolated fashion, but is more often governed by a linked move of the type 
"first pull then push", in which case it is followed by an initiative move, an argument or some sort of assertive move.

Furthermore, there are types of yielding moves which imply giving the initiative away to the other party:

(3) Submitting a proposal explicitly to the other party.

(4) Inviting information or clarifications.

As was hinted at earlier, prosodic and/or kinetic information will be needed in order to judge whether moves that are candidates for this label are predominantly pull-oriented, or if they are rather to be seen as instances of push, either as a basic initiative, such as giving a bid, or as assertiveness, such as requiring information.

Acknowledging moves are moves which aim at strengthening the other party's position or image without necessarily weakening one's own (Brown \& Levinson 1986 would probably not agree on the latter point), by means of recognizing the value of their contribution. In our view, there are two distinct sub-types:

(5) Acknowledging the other party's opinion or argument.

(6) Giving an appraisal, or, in other words, recognizing the other party's "good" properties.

Here again, there may often be doubts as to how to classify a specific move: as an act of pull, as an act of valuating, assertive push, or as both. Further contextualization is always needed, in particular by recurring to prosodic and kinetic information.

A specific way of acknowledging the other party is by means of:

(7) Empathizing. This label refers to what in popular psychology

is called "active listening". An empathizing move means repeating and/or reformulating a statement (opinion, argument, proposal, etc.) made by the other party without making any special valuation of it. The pull effect is obtained through the addressee's feeling of being understood.

We-strengthening moves are defined as moves that do the service of emphasizing and consolidating the bonds between the parties, and thereby, strictly speaking, strengthening both parties' image and position. We have identified the following two sub-types:

(8) Addressing common interests and grounds;

(9) Making reference to the good relationship that is supposed to exist between the parties. 


\subsection{Disguised, linked and ambiguous moves}

Several references have already been made to apparent inconsistencies in the classification done so far. We will here try to synthesize:

In the class labeled "disguised moves", the prevailing type of move is push action that has been disguised as pull. These "push-through-pull" moves may appear either as extremely hedged push moves, or as more or less "off-the-record" and manipulative strategies. An example of the latter category is when the other party's proposal is being paid lip-service to just in order to repeat one's own party's position as though there were no difference between the two standpoints. Likewise, the act of submitting a proposal in a "pulling" fashion to the other party is sometimes used as a simple cover-up for reaffirming one's own party's earlier bid, without (or with hardly) any modifications.

The opposite strategy, "pull-through-push", is extremely rare. We have, in fact, found only one clear instance of this combination, that instance being among Spanish negotiators. This was when one party supposedly criticized the adversaries for "being difficult" but was obviously telling them that there had been a "good fight" and that the atmotsphere had been both stimulating and positive.

The linked moves that were found consisted almost exclusively of "first-pull-then-push" sequences, in which a yielding or acknowledging move reveals itself as belonging to the "counter-argumentative" branch of an argumentative structure (van Eemeren et al. 1983) at the moment when a push move (a basic initiative, an assertiveness manifestation or, more frequently, an argument) follows which contradicts the former assertion. Some stylized examples of this could be the following: "It's OK with us that you do that, but wouldn't it be a better idea if we tried it this other way", or "We agree this is an excellent thing, but have you thought of all the following disadvantages?"

As for the ambiguous, or two-valued moves, two "clashes" have already been commented upon, namely requiring vs. inviting information, and, secondly, showing the generosity of praising, as opposed to allowing oneself to valuate, the other party. Furthermore, the act of giving an explanation can simultaneously be conceived of as a yielding move (providing the other party with what they supposedly want), and as an argumentative one (disguising arguments in favour of one's own position into a seemingly objective explanation).

The first two types-the "disguised" push-through-pull and the "linked" first-pull-then-push move- have caused us no great discomfort 
concerning their theoretical status, nor with regard to the coding process. The disguised move can be viewed theoretically as a special case of a tacit "head act" that is provided with an overt "support". As for the linked moves, they may be viewed as "simple" or "compound" moves, depending on the purpose of the analysis itself.

Where cultural factors start becoming strongly influential is in the field of the ambiguous moves. One culture may attribute a quite different value than another to a specific type of act. But let us first have a look at what may be discovered when the three nationalities' sets of data are contrasted.

\section{The contrastive study: preliminary results}

\subsection{Push moves}

Variation among the three nationality groups was found, not only with regard to the types of moves earlier listed, but also concerning the degree to which (and also the way in which) these moves are attenuated.

\subsubsection{Attenuation of push.}

As a general rule, push moves are produced in a much more attenuated fashion among Swedes than in both Hispanic groups. Their moves are either produced in a generally weaker, less threatening mode, or the threatening moves are more energetically hedged. This statement is valid not only for moves of assertiveness, but also for basic initiatives and for argumentative moves.

The basic initiatives produced by the Swedes show a certain tendency not to appear directly as "bids", "offers" or "claims", but rather as "ideas" or "suggestions", and often they are packaged as argumentative moves in a chain. As for the argumentative moves, the way in which the Swedish negotiators go about the task is strikingly different from the Hispanics. In sharp contrast to the Mexicans, and even more so to the Spaniards, the Swedish negotiators, when presenting their arguments, tend to avoid using references not only to the other party (second person expressions), but also to one's own (first person expressions, excluding types such as "I think" or "we suppose", that would indicate mental operations, cf. Grindsted 1990). This helps to give the Swedish argumentative moves, and chains of moves, a less person-oriented and more task- 
oriented touch. Both parties seem to act as though they were not actually involved in argumentation, defending the own party's position, or challenging the other party, but rather in a kind of problem-solving activity.

\subsubsection{Argumentative moves}

All three nationalities make extensive use of argumentative moves. Both the Mexicans and the Spaniards show a stronger tendency than the Swedes to make recurrent use of the same argument. Furthermore, the Spaniards and the Swedes show a more marked tendency than the Mexicans to get involved in argumentative chains, the difference between them being that the Spaniards do not, as a rule, share the Swedish tendency to mask conflictive issues, but on the contrary are quite capable of enhancing them. Of the three nationality groups, the Swedes are the only ones that show a tendency to disguise their arguments as explanations.

It is not unusual for the Spanish negotiators to build up an argumentative chain before explicitly stating the opinion or claim that is actually being supported. The following exchange between César, the head of Development department, and Benito, a representative of Research lab, provides a good example of this strategy. César's position, left unexpressed up to this point, implies that Research lab should carry out a new series of tests. The frequent hesitation markers and the strong hedging of the successive argumentative moves reveal that there is an important and conflictive point still to be made:

(1) CÉSAR: (...) o sea a a niveles generales habéis realizado una serie de pruebas/ que entendemos que han sido realizadas con un tipo de crudo/de una determinada calidad creo que es proveniente de de méxico/y y bueno pues esto pues siempre supone una cierta: asepsia en cuanto a los resultados que se obtienen/ me explico más e: qué sucedería en el caso de que nosotros utilizásemos un crudo con una composición química totalmente diferente a su: proveniente de los emiratos árabes/ en el cual pues podríamos tener en cuenta como consecuencia de una desactivación de de este catalisis/ de este catalizador de tipo heterogéneo que nos estáis que nos estáis proponiendo/ es decir/ nosotros estamos viendo que hay una dificultad que bueno que me parece que puede ser se puede salvar perfectamente mientras mediante una colaboración mutua de de de nuestros departamentos/ es decir creo que debemos de aportar a los departamentos recursos tanto técnicos como humanos para solventar este problema y luego hay otro problema otro problema

(...) that is, generally speaking, you've carried out a number of tests which we understand have been carried out with a type of crude oil of a specific quality, I believe it's from Mexico, and, and, well, now this, now 
this always carries along a certain "asepticity" [=scepticism] concerning the results obtained. I'll make myself clear, right, now, what would happen in the case we used a crude with a totally different chemical structure from, er, coming from the Arab emirates? In which, er, we could take into account as a consequence of the deactivation of, of this catalyze, this catalyst of the heterogeneous type you are, you are proposing to us, which means, we can see there is a difficulty that, well, it seems to me that one could, it could be arranged perfectly well while, through mutual cooperation on behalf of, of, of our departments, that is, I believe we should let the departments have both enough technical and human resources to solve this problem. And then there is another problem, another important...

BENITO: es decir

Which means...

CÉSAR: importante que (...)

...problem, which (...)

In all nationality groups, the arguments that are directly addressed against the other party's position are avoided, and "arguments-for" are generally preferred. This tendency, however, is less pronounced among the Spaniards and Mexicans than among the Swedes. When "argumentsagainst" are actually put forward, the Spaniards share the Swedish preference of addressing them to one's own "counter-argumentative" move, rather than to an argument put forward by the opposite party. This means that the linked "first-pull-then-push" type is more frequent in each of the European groups than among the Mexicans.

\subsubsection{Assertive moves}

The Mexican negotiators are the ones that make the most extensive use of assertive moves. In fact, all sub-classes of these moves are well represented in the Mexican data, and they are often strikingly "bald-onrecord". In the following sequence, which takes place within the first minute of the negotiation, Benito, who is a representative of Research lab, vehemently rejects the proposal put forward in a very direct way by Celia, one of the representatives of Development department:

(2) Celia: (...) pues: e: una prueba/ que ustedes nos entregaron hace días/ en la cual nosotros al: depa a los gerentes de producción se la mostramos/y ellos pues realmente no están muy satisfechos con esa prueba sí/precisamente por eso e: nos estamos reuniendo pues para solicitarles que: e: fue insuficiente/esa prueba y: requerimos que: nos apoyen para otra prueba más 
(...) well, er, a test result you gave us a few days ago, which we showed the depart, the production managers, and they were not very pleased with that test, right. It's precisely for that reason, er, that we are having this meeting, er, to ask you to, er, it was insufficient, that test, and, er, we request, er, that you give us your support for another testing.

BENITO: e: definitivamente a nosotros no estamos de acuerdo/en una segunda prueba/consideramos que este nuevo proceso/es el invento/más grande en los últimos treinta años de la compañía/y definitivamente nosotros necesitamos que nos publiquen/oficialmente ante toda la corporación/e: el proyecto

Er, for us, definitely, we do not agree with this second testing. We consider this new process to be the company's greatest invention for the last thirty years, and we definitely need for it to be published officially in the whole corporation, er, this project.

The Spaniards are less inclined than the Mexicans to resort to nonargumentative assertive behaviour, although they do it much more often than the Swedes. When Spaniards use assertive moves, they share the Mexican tendency of acting "bald-on-record". Although Swedes are the least willing to show non-argumentative assertiveness, certain types are more strongly represented than others. For instance, warnings, or mild reprehensions, which aim at holding the other party responsible for future setbacks, are not infrequent. In two of the three Swedish interactions studied, a development department representative starts the negotiation by underscoring, discreetly but efficiently, his/her relative power position by stating "we summoned this meeting in order to come to terms with a few issues".

\subsection{Pull moves}

In all three groups, the proportion of push moves is many times higher than that of pull moves, a fact which is hardly surprising, considering the fact that negotiations as a general rule seem to be conceived of as a typically competitive activity throughout the Western world. In the Swedish data, however, pull moves occur approximately twice as frequently as in both Hispanic sets of data.

In the Spanish data, pull moves are especially frequent in the initial "warm-up" phase of the negotiation; in this phase, a considerably larger amount of energy is spent in the Spanish groups than among the Swedes or the Mexicans. As would be expected for this phase, it is the westrengthening type of move that is most strongly represented. 
Among the Mexicans, pull moves tend to become abundant only towards the end of the negotiation, when an agreement has already been reached, or is within sight. Here again, the we-strengthening type is the most strongly represented, interspersed with acknowledging moves. It seems as though both parties felt the obligation of rewarding each other after a fierce battle, which has been a challenge to their cohesion. The following excerpt provides a good example of end-phase pull exchanges (Antonio and Benito represent Research lab, Carlos and Diego are from Development department):

(3) CARLos: (...) no/ y y y y el objetivo de ser del departamento de de: procesos desarrollo de procesos e: creo que está muy claro para ustedes/ pero valdría la pena / pues concientizarlos de que estamos respaldándo$\operatorname{los} /$

(...) right, and, and, and the reason why we exist, the department of, of process development, er, I believe is very clear to you, but it may be worthwhile, er, to make you aware that we're backing you up...

ANTONIO: claro

Of course!

CARLOS: realmente

...indeed,...

CARLOS: nuestra razón de ser es respaldar al departamento a los los ...our reason for existing is to back up the department, the, the...

ANTONIO: así es/ entonces lo que les iba a comentar no/ finalmente lo que necesitamos de ustedes e:s su apoyo/ porque si ustedes no creen en nosotros/ pues se complica [laughing]

That's it. So what I was going to tell you, right, finally, what we need from you, that's, er, your support, because if you don't believe in us, er, things get complicated [laughing].

CARLos: nosotros vamos a cree- cómo vamos a comercializar un producto del que no tenemos

Are we going to belie-, how could we go marketing a product that we aren't...

ANTONIO: claro

Of course!

CARLOS: la plena y absoluta

... completely and absolutely...

CARLOS: seguridad/ primero de que va atener aceptación en el mercado/ que es lo mejor de lo que existe en estos momentos/ y que va a ser rentable

...sure of, first of all that it'll be welcomed by the market, that it's the best there is at the moment, and that it's going to be profitable? 
ANTONIO: ah ya

Oh, yeah.

CARLOS: entonces ahí es e:

So there's, er, ...

CARLOS: de hecho ustedes son los científicos y nosotros los comercializadores/ y nosotros estamos en la mejor disposición/ de que precisamente todos los productos que ustedes lancen al mercado salgan en tiempo/ no nos gane la competencia/ estamos trabajando en el mismo barco

...in fact, you're the scientists and we're the business people, and we are perfectly ready, precisely to make all the products you launch on the market come out in time, so that our competitors won't get us, we're all working in the same boat!

BENITO: exacto

Exactly!

DIEGO: los cerebros son

The brains , that's...

DIEGO: ustedes/ los que piensan y descubren/ y tienen mucha imaginación son ustedes/ con el apoyo de nosotros e: podemos salir adelante ...you, those who think and discover, and have lots of imagination, that's you. With our support, er, we can make it!

This kind of sequence among the Mexican negotiators constitutes a sharp contrast to the sometimes strongly competitive atmosphere that characterizes the rest of the negotiation, including the very onset.

Yielding and acknowledging moves are much more frequent among the Swedes than among the Hispanic groups. One type of move that is hardly ever produced in the Mexican groups-and never among the Spaniards-but stands out as fairly frequent in the Swedish data, is empathizing with the other party. The following example is a rather typical one. Here, Cecilia, a Research lab representative, tries to reformulate in a discreet manner the proposal (already very strongly hedged) that has been put forward by Anders, a Development department representative:

(4) ANDERS: men vi vill ju egentligen inte avkräva er några garantier/

But we really don't want to demand any guarantees from you,...

CECILIA: nej

Oh no.

ANDERS: och så där

.... and so forth,...

ANDERS: men om det fanns garantier för att det här testet är tillförlitligt så är/ så skulle ju det vara okey också/

...but if there were guarantees for the reliability of this test, then it's, then it would of course be OK too. 
CECILIA: du vill ha en garant / du vill ju / du vill [pause]/ du vill förvissa dig om då att vi har en sä / en säkrare / va / va skulle/ va skulle vi behöva göra för att ni skulle känna er säkrare /

You want a guaran-, of course you want, you want [pause], you want to make sure then that we have a sa-, a safer-. What, what would, what would you need for us to do in order for you to feel more secure?

\subsection{Ambiguous moves}

Certain types of moves are likely to score much higher points in one culture than another on their respective "push" and "pull scales". It seems to be the case, for instance, that among Spanish negotiators, certain types of argumentative moves acquire, along with their inherent push interpretation, a we-strengthening, i.e. pull, value, as soon as they get responded to. This is probably also true of many assertive moves, such as valuating and admonishing statements. It may even be questioned whether a direct, positive valuation will be considered by Spaniards to be "pushy" at all, as it is likely to be interpreted by Swedes. Conversely, demanding information will probably have a stronger push value on both the Spanish and the Mexican scale than on the Swedish one.

The fact that certain moves, seemingly "pushy" by their nature, are arranged so as to acquire a clearly integrative interpretation; this is illustrated by behaviour which was produced in two of the three observed Spanish negotiations, and for which we will suggest the label "co-operative bargaining". In the following excerpt the negotiators, after an extended period of intense argumentative fighting, seem to have realized that the parties are not too far off from each other, and they start a process of yielding their respective contributions to a settlement (Ana and Benito are the Research lab representatives, and Diego is the head of the Development department):

(5) DIEGO: o sea vamos a fijar diríamos cuatro etapas eh

Which means, we'll set up say four steps, right?

BENITO: bien

Fine.

DIEGO: la primera etapa e: sería presentárselo en común a nuestra

The first step, er, would be to make a conjoined presentation to our, ...

ANA: a nuestra central

To our head office.

DIEGO: a nuestra central eh ...to our head office, right? 
BENITO: cuándo

When?

DIEGO: pues yo creo que

Well, I think that...

AnA: eso ya

That should be done at once.

DIEGO: ya

$O K$.

BENITO: bien mañana en la mañana

Alright, tomorrow morning.

DIEGO: no no porque creo que en la en el informe deberíamos de recoger como la cláusula final el el hacer una nueva prueba con

Oh no, because I think that in the report we should put in the last paragraph that, that we are going to carry out a new test with...

BENITO: sí pero bueno eso eso lo tenemos bien el lunes

Yes but, well, that, that we'll have on Monday, right?

ANA: el lunes

On Monday.

DIEGO: el lunes

On Monday?

Benito: perfecto

Perfect.

DIEGO: de inmediato

Next monday?

BENITO: el lunes en tres días en tres días

On Monday in three days' time, in three days' time.

DIEGO: ese sería el primer proceso

So that'd be the first process.

The moves considered to possess the strongest push value are also those that are in greatest need of attenuation. Overt criticism, to Swedes, is a dangerous activity that requires not only hedging, but often even masking. The following excerpt provides a good example of such a disguised move. Here, an extended explanatory account is the cover-up for a strong attitude of criticism obviously held by Albert, a Development department representative, towards the Research lab representatives Cedrik and Dora: 
(6) AlbeRT [clears his throat]: vi känner oss ju inte/ nej dom går inte/ du menar att personalen går över [DORA: ja] dotterbolagen [DoRA: ja] / utan dom [DoRA: ja] läcker ut information

[clears his throat] Of course we don't feel, no, they won't go, you mean the staff goes to [DORA: yes] the subsidiaries [DORA: yes], so in fact they're [DORA: yes] leaking information.

DORA: jasså dom är inte tysta/ ajaja/ då förstår jag aha So they're not silent? Oh dear, then I see, aha.

CEDRIK: dom pratar för mycket om det här

They're talking too much about these things.

AlBERT: ja just det/ dom läcker information sörru / [DORA: jaa] dom / dom känner till ute i dotterbolagen resultatet [DORA: mmmm] utav testerna innan vi har utvärderat testerna och det / då vänder dom sig till oss och så säger dom varför får vi inte den här processen snabbare/ som verkar va så bra

Yes exactly, they're leaking information, you see [DORA: yeah]. They know in the subsidiaries about the results [DORA: mmmm] of the testing before we've evaluated the tests, and that, then they'll turn to us and they'll say, why don't we get this process quicker, that seems so good.

DORA: jaha ja

Oh yes, aha.

AlBERT: och det är det som [DoRA: mm] är lite besvärande för oss/ [DORA: $\mathrm{mm}$ ] då att då får ju vår personal som får dom här signalerna/ dom jagar kanske fram resultat då som inte är helt tillförlitliga (...)

And that's what's a bit [DORA: mm] troublesome to us [DORA: mm], then, that then our staff, who receives these signals, perhaps they'll be in a hurry to show results, then, that aren't quite reliable (...)

\section{The results as compared to sociological/anthropological reports on cultural differences.}

To summarize, the following generalizations may be proposed on the basis of observations made on the different nationality groups

- The Swedes make a more extensive use of pull strategies than do the Mexicans and the Spaniards.

- The Swedes typically produce their push moves in a more attenuated fashion than do the Hispanics.

- Both the Swedes and the Spaniards show a more marked preference for constructing argumentative chains than do the Mexicans, who in their 
turn are more prone to repetitive argumentation than the other two groups, especially the Swedes.

- The Mexicans use fewer linked moves of the "first-pull-then-push" type.

- The Mexicans show the highest proportion, and the widest variety, of assertive moves. Next in line come the Spaniards. Assertive moves among the Swedes, as a rule, are strongly hedged, and the most salient types are reprehending / holding responsible and underscoring (discreetly) one's own power.

- Pull moves among the Spaniards prevail in the initial phase of the negotiation. We-strengthening moves are the most strongly represented type of pull action.

- Pull moves of the we-strengthening and acknowledging sub-classes prevail among the Mexican negotiators in the final phase, when an agreement has already been reached.

- Yielding and acknowledging moves are more frequent among the Swedes than among the Hispanic groups.

To what extent are these results-obtained with conversation analysis methods-consistent with sociological and anthropological work on culturally determined behaviour differences? It would be beyond the scope of the present study to try to analyze this aspect in depth. Still, there are a few points which may be useful to consider.

According to Hofstede (1991), Swedes occupy a high position on the "individualism" scale, a low position on the "power distance" and "uncertainty avoidance" scales, and an extremely low position on the "masculinity" scale. A combination of high individualism, interpreted as a strong tendency to maintain personal autonomy, and low masculinity, conceived of as a low evaluation of "pushy" behaviour, may partly account for the Swedish tendency to attenuate push moves and to restrict their number, as well as the Swedish preference for "impersonal" argumentation and for pull action of the yielding kind. The Swedish preference for establishing consensus (Daun 1989:102-123), and in particular of considering consensus as a necessary condition for carrying on meaningful conversation (Fant 1992b: 147), contributes to explaining the strong control of push action, and the relatively widespread use of acknowledging, in particular empathizing, moves. 
The high Mexican power distance index in the Hofstede measurements, combined with a high masculinity index, may be an important factor in explaining why the Mexicans have a more "challenging" style in their push behaviour than do the Spaniards (intermediary power distance and masculinity values), let alone the Swedes (low power distance, low masculinity). A high power distance index, taken together with low values for individualism, may also account for the striking Mexican "family" atmosphere, with its rapid switches between highly cooperative and blatantly competitive behaviour.

The high uncertainty avoidance index which characterizes both Spaniards and Mexicans in Hofstede's study may help to explain the relatively high frequency of we-strengthening moves. Observations to the same effect were found by the present author (Fant 1989: 251-2, and Fant 1992b: 147), who attributed this tendency among Spanish negotiators to general preferences for person-oriented action. A meaningful dialogue presupposes that there be mutual personal acceptance, and that an atmosphere of confianza is established, with an agreement that "I will be helpful to you if you will be helpful to me". This appears to be a tendency shared by both Hispanic groups, and an important feature which separates Scandinavian from Hispanic behaviour, not only in negotiations but also on a more general plane.

\section{References}

Allwood, J. (1976): Linguistic communication as action and cooperation. Gothenburg Monographs: In: Linguistics 2. University of Gothenburg.

Allwood, J. (1980): On the analysis of communicative action. In: M.Brenner (ed.), The Structure of Action. Oxford: Blackwell \& Mott.

Andersen, F.G. (1990): Repetition Structures and Formulas in English and Danish Business Negotiations. In: Merino 6. University of Odense.

Bilmes, J. (1986): Discourse and Behavior. New York: Plenum.

Blum-Kulka, Sh., J. House \& G. Kasper (1989). Investigating cross-cultural pragmatics: an introductory. In: Sh. Blum-Kulka, J. House \& G. Kasper (eds.), Cross-cultural pragmatics: requests and apologies. Norwood: Ablex. 1-34.

Brown, P. \& S. Levinson (1986): Politeness. Cambridge: CUP.

Daun, Å. (1989): Svensk mentalitet - ett jämförande perspektiv. Stockholm: Rabén \& Sjögren.

Donohue, W. A. (1981): Analyzing Negotiating Tactics: Development of a Negotiation Interact System. In: Human Communication Research 10, 273-287.

Duranti, A. (1990): Frames, events and boundaries: two models and some cross-contextual, cross-cultural reflections. Paper presented at 1990 International Pragmatics Con- 
ference, Barcelona (Spain).

Eemeren, F.H. van, R. Grootendoorst \& T. Kruiger (1983): The Study of Argumentation. New York: Irvington.

Fant, L. (1989): Cultural mismatch in conversation: Spanish and Scandinavian communicative behaviour in negotiation settings In: Hermes 2, 247-265.

Fant, L. (1992a): Analyzing negotiating talk - authentic data vs. role play. In: A,. Grindsted \& J. Wagner (eds.), Communication for Specific Purposes / Fachsprachliche Kommunikation. Tübingen: Gunter Narr. 164-175.

Fant, L. (1992b): Scandinavians and Spaniards in negotiations. In: A. Sjögren \& L. Janson (eds.), Culture and management in the field of ethnology and business administration. Botkyrka: The Swedish Immigration Institute and Museum.

Fant, L., S, Norlén \& L. Westholm (forthcoming). Emotion in negotiations: how Spaniards and Swedes judge each other's communicative style. Unpublished manuscript. Stockholm University.

Firth, A. (1990): Responding to proposals: an analysis of "alignment-talk" in trading negotiations. Papers on Languages and Intercultural studies. Aalborg University.

Goffman, E. (1972): On face-work. An analysis of ritual elements in social interaction. In: J. Laver \& S. Hutcheson (eds.), Communication in face-to-face interaction. Harmondsworth: Penguin. 319-346.

Grindsted, A. (1990): How conversation is organized in Spanish and Danish negotiation interaction. In: Merino 7. University of Odense.

Hofstede, G.H. (1991): Cultures and organizations. Software of the Mind. Maidenhead: McGraw-Hill.

Karrass, Ch. L. (1974):. Give and Take: The Complete Guide to negotiating Strategies and Tactics. New York: Thomas Y. Crowell.

Lampi, M. (1990): Business negotiations: linguistic strategies and the company agenda. Paper presented at AILA Conference 1990, Thessaloniki (Greece).

Nierenberg, G. I. (1973): Fundamentals of negotiating. New York: Hawthorn.

Searle, J. (1979): Expressions and Meaning. Studies in the Theory of Speech Acts. Cambridge: CUP.

Wierzbicka, A. (1992): Cross-Cultural Pragmatics. Berlin, etc.: Mouton de Gruyter. 
